TITLE:

\title{
Analysis of Mixture Formation Process in a Diesel Engine with Post Injection
}

AUTHOR(S):

Horibe, Naoto; Komizo, Tatsuya; Mamizuka, Yuji; Sumimoto, Takashi; Kawanabe, Hiroshi; Ishiyama, Takuji

\section{CITATION:}

Horibe, Naoto ...[et al]. Analysis of Mixture Formation Process in a Diesel Engine with Post Injection. SAE Technical Papers 2015: 2015-01-1836.

\section{ISSUE DATE:}

2015-09-01

URL:

http://hdl.handle.net/2433/237659

\section{RIGHT:}

This is the accepted manuscript of the article, which has been published in final form at https://doi.org/10.4271/2015 01-1836:; The full-text file will be made open to the public on 1 March 2016 in accordance with publisher's 'Terms and Conditions for Self-Archiving'; This is not the published version. Please cite only the published version.; この論文は出版 社版でありません。引用の際には出版社版をご確認ご利用ください。 


\title{
Analysis of Mixture Formation Process in a Diesel Engine with Post Injection
}

\author{
Naoto Horibe, Tatsuya Komizo, Yuji Mamizuka, Takashi Sumimoto, Hiroshi Kawanabe, \\ and Takuji Ishiyama \\ Kyoto University
}

Copyright (c) 2015 SAE Japan and Copyright @ 2015 SAE International

\begin{abstract}
A series of experiments was conducted using a singlecylinder small-bore $(85 \mathrm{~mm})$ diesel engine to investigate the smoke-reduction effect of post injection by varying the number of injection nozzle orifices and the injection pressure. The experiments were performed under a constant injection quantity condition and under a fixed NOx emission condition. The results indicated that the smoke emission of six-hole, sevenhole, and eight-hole nozzles decreased for advanced post injection, except that the smoke emission of the 10-hole nozzle increased as the post injection was advanced from a moderately late timing around $17^{\circ}$ ATDC. However, the smoke emission of the 10hole nozzle with a higher injection pressure decreased for advanced post injection. These trends were explained considering the influence of the main-spray flames on post sprays based on CFD simulation results.
\end{abstract}

\section{INTRODUCTION}

Multiple-stage injection is one of the important strategies for controlling combustion in diesel engines to realize a reduction in pollutant release with a high thermal efficiency and low combustion noise. Many studies have been carried out on the reduction in soot emission from diesel engines by close-coupled post injection, in which a small amount of fuel is injected during the combustion of main sprays [1-21]. Among them, several studies have demonstrated the sootreduction effects of post injection and investigated the soot-reduction mechanisms for heavy-duty diesel engines [15-21]. For example, O'Connor and Musculus [18] performed experiments using a heavy-duty (HD) optical diesel engine. They indicated that the addition of optimal post injection reduced soot emission at high intake-oxygen levels in spite of the increase in the total injection quantity. It suggested that the soot reduction is brought by the interaction between the post-injection sprays and the soot cloud from the main-injection sprays. At low intake-oxygen levels, post injection could reduce soot emission compared to the case without post injection for the same load, and the soot emission level was comparable to the case when the post injection is removed. Hessel et al. [17] performed a computational fluid dynamics (CFD) analysis for high intake-oxygen conditions in an HD diesel engine. As the reasons for the reduction in soot by post injection, they indicated that soot from short-post injections were well oxidized, and the short-post injections consumed residual fuel vapor from the main injection.

Studies have also been carried out for post-injection effects in small-bore diesel engines [6, 8, 11, 13]. Hotta et al. [6] performed experiments using a diesel engine with a bore of $83 \mathrm{~mm}$. They indicated that advanced post injection reduced smoke emission for a low load. On the basis of results using an optical engine and a CFD analysis, they described that post-injection jets carry the soot from the main-spray combustion to the squish area and then oxidize it. Ikemoto et al. [11] also indicated similar smoke-emission trends versus the post-injection timing in a small-bore diesel engine. However, they suggested another smoke-reduction mechanism for post injection on the basis of the results of experiments using a bottom-view optical engine: the main-spray flames impinge on the side wall of the piston bowl and flow along the bottom of the piston bowl to the center region of the combustion chamber; then, the main-spray flames block the path of the post sprays. When applying early post injection, post sprays entrain air remaining in the center region of the combustion chamber before the main-spray flames block the path. To obtain the same load as in the case without post injection, the main-injection quantity is decreased by using post injection. As a result, the soot from the main sprays decreases, and the soot from the post sprays is low owing to the utilization of air in the center region, as described above.

On the other hand, Desantes [8] performed experiments using a small-bore diesel engine and reported that the smoke emissions were hardly influenced by post injection in the case of a small amount of post injection, and advanced post injection increased smoke emission in the case of large post injection. Thus, the smoke-emission trend versus the post-injection timing and the suggested reasons for the trend are very diverse. Further study is required to clarify the relationship between the soot-reduction 
effects and the specifications and operational conditions of engines.

In our previous study [22], an experimental study was performed using a small-bore single-cylinder diesel engine by changing the post-injection timing for various post-injection quantities, injection pressures, main-injection timings, intake pressures, numbers of injection nozzle orifices, and combustion chamber shapes. The results indicated that close post injection provides lower smoke emission for the combination of a reentrant combustion chamber and seven-hole nozzle. The same trend was also found in tests that varied the injection pressure, main-injection timing, and intake pressure. However, a lower sensitivity of the smoke emission to the post-injection timing was observed when using a 10-hole nozzle with the same hydraulic flow rate compared to the seven-hole nozzle or a toroidal combustion chamber.

The objective of this study is to clarify the reason for such the change in the relation between smoke emission and post-injection timing and to provide the knowledge for proper selection of post injection conditions. For the purpose, a series of experiments were carried out focusing on the effect of number of nozzle orifice using a single-cylinder diesel engine. The post-injection timing was changed using six- to 10hole nozzles with the same hydraulic flow rate and injection pressure for a 10-hole nozzle.

The experimental data for the performance and exhaust emissions were obtained under a constant injection quantity condition of approximately 1.0 MPa for the indicated mean effective pressure (IMEP). In addition, CFD simulations were carried out to analyze the distributions of the mixture fraction and temperature, which had a strong relationship to soot formation and oxidation. Explanations for the trends in smoke emission in the experiments were attempted considering the influence of the main-spray flames on post sprays based on the CFD simulation results.

\section{EXPERIMENTAL SETUP}

The experimental system and measurement methods used in this study were essentially the same as those reported in the previous study [22]. The test engine was a water-cooled single-cylinder four-stroke-cycle direct-injection diesel engine. The major specifications of the engine are listed in Table 1. To regulate the intake charge condition, an external supercharger and intercooler were installed. A low-pressure loop EGR system was employed, including a diesel particulate filter (DPF) to protect the supercharger from soot contamination.

The experimental conditions are listed in Table 2. All of the experiments were performed under a thermal steady state for the engine at a fixed speed of $1,500 \mathrm{rpm}$, an inlet coolant temperature of $80^{\circ} \mathrm{C}$, and a lubricating oil temperature of $80^{\circ} \mathrm{C}$. The fuel was commercial JIS No. 2 diesel fuel (density at $15^{\circ} \mathrm{C}$ : $832.2 \mathrm{~kg} / \mathrm{m}^{3}$, cetane index: 57 ). All of the fuel-injection nozzles had the same hydraulic flow rate $(680 \mathrm{~mL} / \mathrm{min}$ @ $100 \mathrm{kPa})$ and spray angle $\left(156^{\circ}\right)$. The standard nozzle was a seven-hole nozzle. The total injection
Table 1 Major engine specifications.

\begin{tabular}{|l|l|}
\hline Engine type & $\begin{array}{l}\text { Direct-injection, } \\
\text { single-cylinder, } \\
\text { water-cooled diesel engine }\end{array}$ \\
\hline Displacement $\left.\mathrm{cm}^{3}\right]$ & 550 \\
\hline Bore [mm] & 85.0 \\
\hline Stroke [mm] & 96.9 \\
\hline Compression ratio [-] & $16.3: 1$ \\
\hline $\begin{array}{l}\text { Combustion chamber } \\
\text { shape }\end{array}$ & $\begin{array}{l}\text { Reentrant } \\
\text { (Cavity dia. 51.6 mm) }\end{array}$ \\
\hline Number of valves [-] & 4 (Intake 2, Exhaust 2) \\
\hline Injection system & $\begin{array}{l}\text { Common-rail system } \\
\text { with solenoid injector } \\
\text { (Max. press.: 180 MPa) }\end{array}$ \\
\hline Supercharging & External supercharging \\
\hline EGR system & Low-pressure loop EGR \\
\hline
\end{tabular}

quantity was set at $33 \mathrm{~mm}^{3} /$ cycle, where the IMEP was approximately 1.0 MPa. On the basis of the previous study [14], the pilot injection quantity was set at $6 \mathrm{~mm}^{3} /$ cycle to realize the entirely mixing-controlled combustion of the main spray and a relatively high smoke level for easy detection of the soot-reduction effect of post injection. The intake manifold pressure and temperature were adjusted to $120 \mathrm{kPa}$ and $35^{\circ} \mathrm{C}$. The NOx emissions in all cases were maintained at $150 \pm 5 \mathrm{ppm}$ by adjusting the EGR rate to eliminate the difference in the NOx emissions caused by the change in the post-injection timing. As a result, the EGR rate was between $20 \%$ and $25 \%$, and the equivalence ratio was approximately 0.8 . The post-injection timing was varied from $11^{\circ} \mathrm{ATDC}$, which was the most advanced timing, to $21^{\circ}$ ATDC. The most advanced timings were selected to prevent unstable injection caused by the limitation of the injector response, where the injection dwell between end of main injection and start of post injection was $0.19 \mathrm{~ms}$. The post-injection quantity was maintained at a constant value by adjusting the duration of the post-injection signal.

The injection durations and delay times from the injection command to the start of actual injection were obtained from the experiments using a Bosch-type injection rate meter. Those were acquired by the same injection pressures, injection command dwells, and injection command durations as those applied in the engine experiments. On the basis of the results, the actual injection timings and durations are displayed in the graphs.

\section{NUMERICAL SETUP}

A CFD simulation was performed using AVL FIRE $®$ v2010. The major submodels used in the simulation are listed in Table 3. The liquid phase of the fuel was treated by a discrete droplet method, and the KelvinHelmholtz/Rayleigh-Taylor (KH-RT) model was adopted for spray breakup. The model constants for the KH-RT model were used according to the FIRE $®$ recommendation [23]. The spray angle was $12^{\circ}$ on the basis of a shadowgraph image of a spray in a high- 
Table 2 Engine operating conditions.

\begin{tabular}{|c|c|}
\hline Engine speed [rpm] & 1,500 \\
\hline Fuel & $\begin{array}{l}\text { JIS No. } 2 \text { diesel fuel } \\
\text { (cetane index: } 57 \text { ) }\end{array}$ \\
\hline $\begin{array}{l}\text { Injection nozzle } \\
\text { hole dia. }[\mathrm{mm}] \times \text { num. }[-]\end{array}$ & $\begin{array}{l}\phi 0.135 \times 6 \\
\phi 0.125 \times 7 \text { (standard) } \\
\phi 0.117 \times 8 \\
\phi 0.105 \times 10\end{array}$ \\
\hline Injection pressure [MPa] & 90 (standard), 130 \\
\hline Total-inj. quantity [mm³/cycle] & 33 \\
\hline Pilot-inj. quantity [mm³/cycle] & 6 \\
\hline Pilot-inj. timing [ ${ }^{\circ}$ ATDC] & -19 \\
\hline Main-inj. quantity [mm³/cycle] & $\begin{array}{l}23 \\
(27 \text { for the case } \\
\text { without post injection) }\end{array}$ \\
\hline Main-inj. timing $\left[{ }^{\circ}\right.$ ATDC] & 1 \\
\hline Post-inj. quantity [mm³/cycle] & 4 \\
\hline Post-inj. timing [ ${ }^{\circ}$ ATDC] & $11-21$ \\
\hline Swirl ratio [-] & 1.8 \\
\hline Intake pressure [kPa (abs.)] & 120 \\
\hline Intake temperature $\left[{ }^{\circ} \mathrm{C}\right]$ & 35 \\
\hline NOx emission [ppm] & $150 \pm 5$ \\
\hline
\end{tabular}

temperature and high-pressure atmosphere in a constant-volume vessel. N-heptane was used to model the diesel fuel, and Kawanabe's reduced chemical kinetics model was used for primary reference fuel [24]. This model includes 42 species and 69 chemical reactions. The nonhomogeneous mixture auto-ignition (NMA) model [24] was employed to consider the autoignition process in a locally nonhomogeneous mixture.

To analyze the effect of the number of injection nozzle orifices, simulations were carried out for seven-hole and 10-hole nozzles. To maintain a reasonable computational time, one-seventh and one-tenth sector meshes were modeled for the seven-hole and 10-hole nozzles. An example of the grid system is shown in Fig. 1. The total number of cells for the seven-hole nozzle was approximately 27,000 at TDC. In the simulation, the shape of the injection rate was modeled on the basis of the experimental results: the injection duration was equal to the experiment. However, the injection rate was increased to obtain an equal injected calorific value per unit time in the simulation, because $n$ heptane has a slightly lower heating value than diesel fuel. The initial gas composition at intake-valve closing (IVC) was constant regardless of the test conditions, although the intake-charging gas composition was

Table 3 Submodels used in CFD.

\begin{tabular}{|l|l|}
\hline CFD solver & FIRE® v2010 \\
\hline Spray breakup & KH-RT \\
\hline Turbulence & k-epsilon \\
\hline Chemical kinetics & $\begin{array}{l}\text { Kawanabe [24] } \\
\text { (42 species, 69 reactions) }\end{array}$ \\
\hline Combustion & NMA [24] \\
\hline
\end{tabular}

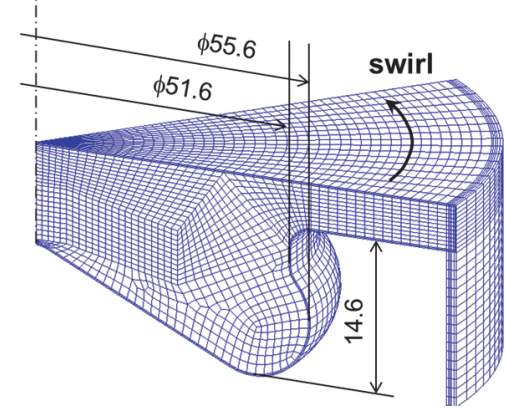

Figure 1 Grid systems for the seven-hole nozzle at $20^{\circ} \mathrm{CA}$.

Table 4 Initial values in CFD.

\begin{tabular}{|c|c|}
\hline $\begin{array}{l}\text { In-cylinder pressure } \\
\text { at } 145^{\circ} \mathrm{BTDC}\end{array}$ & $123 \mathrm{kPa}$ \\
\hline $\begin{array}{l}\text { In-cylinder temperature } \\
\text { at } 145^{\circ} \mathrm{BTDC}\end{array}$ & $338 \mathrm{~K}$ \\
\hline Initial gas composition & \\
$\mathrm{N}_{2}$ & $78.7 \%$ \\
$\mathrm{O}_{2}$ & $16.7 \%$ \\
$\mathrm{CO}_{2}$ & $2.5 \%$ \\
$\mathrm{H}_{2} \mathrm{O}$ & $2.1 \%$ \\
\hline
\end{tabular}

slightly changed according to the test conditions. The initial conditions are summarized in Table 4.

\section{RESULTS AND DISCUSSION}

First, experiments and CFD simulations were carried out for seven-hole (standard) nozzle and the smoke tendency against post-injection timing was explained based on the influence of the main spray flame on the post spray. And then, in order to examine the effect of the number of nozzle orifice in more detail, a series of experiments were conducted for the nozzles with six through 10 holes. As a result, the 10-hole nozzle showed the different smoke tendency against postinjection timing compared with other nozzles. CFD simulation therefore was performed tor 10 -hole nozzle and the difference in influence of the main spray flame on the post spray was clarified.

\section{EFFECT OF POST-INJECTION TIMING}

The effect of the post-injection timing was investigated with a seven-hole nozzle. Figure 2 shows the smoke emission, intake oxygen concentration $\mathrm{O}_{2 \text {,in }}$, and indicated thermal efficiency $\eta_{\mathrm{i}}$ versus the post-injection timing $\theta_{\text {post. }}$. The results of the case without post injection are also shown. The intake oxygen concentration decreased to maintain constant NOx emission for more advanced post injection. Nevertheless, the smoke emission decreased for more advanced post injection. This smoke-emission tendency is same as the results in [6] and [11]. The indicated thermal efficiency slightly increased with the advance of post injection and reached almost the same level as the case without post injection. The $\mathrm{CO}$ and THC emissions were sufficiently low and were hardly affected by the post-injection timing. 


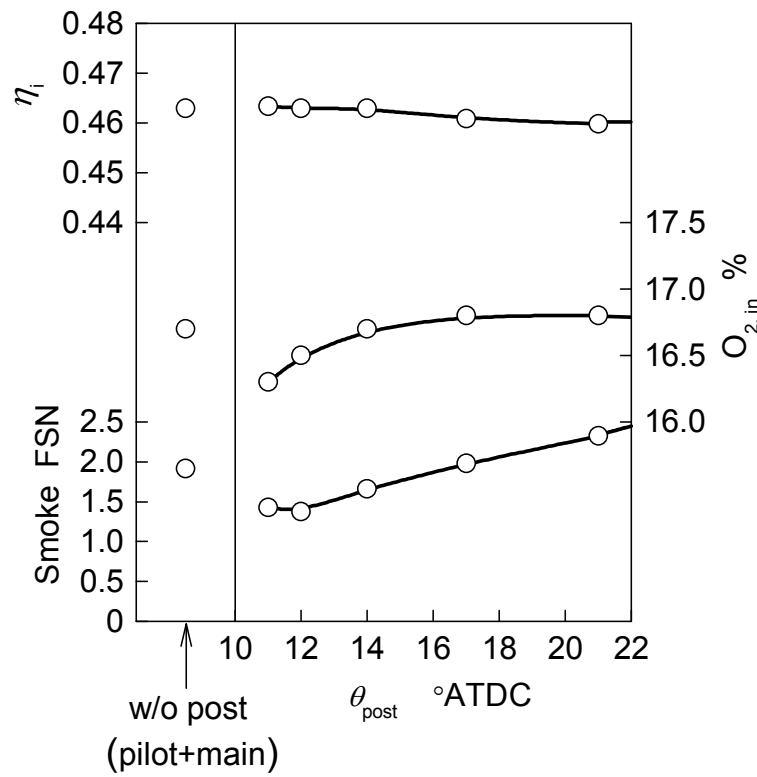

Figure 2 Effects of the post-injection timing on the indicated thermal efficiency $\eta$, intake oxygen concentration $\mathrm{O}_{2}$,in, and smoke emission (experimental results).

To understand the reason for the smoke-emission tendency, a CFD analysis was conducted for the experimental conditions in Fig. 2. To validate the CFD simulations, the calculated in-cylinder pressures $p$ and heat-release rates $\mathrm{d} Q / \mathrm{d} \theta$ were compared with those from the experiments for post-injection timings $\theta_{\text {post }}$ of $11^{\circ}$ ATDC and $21^{\circ}$ ATDC. The results are shown in Fig. 3 . The calculated in-cylinder pressures and heatrelease rates exhibit good agreement with the experimental data, although the peak of the heatrelease rate around $25^{\circ} \mathrm{CA}$ for $\theta_{\text {post }}=21^{\circ} \mathrm{ATDC}$, which is caused by post injection, is higher than that in the experiment.

To examine the spatial distribution of the fuel-air mixture, which would have a strong correlation with soot formation/oxidation, the calculated distributions of the mixture fraction $f_{\mathrm{u}}$ were analyzed. $f_{\mathrm{u}}$ is defined as follows:

$$
f_{\mathrm{u}}=\frac{m_{\mathrm{f}}}{m_{\mathrm{f}}+m_{\mathrm{a}}}
$$

where $m_{\mathrm{f}}$ is the fuel mass, and $m_{\mathrm{a}}$ is the surroundinggas mass. Because $m_{\mathrm{f}}$ and $m_{\mathrm{a}}$ are calculated from the mass of $\mathrm{C}$ and $\mathrm{O}$ included in all chemical species, $f_{\mathrm{u}}$ is determined only by the evolution of fuel-air mixing and is not influenced by the progress of chemical reactions. Under the conditions in this study, $f_{\mathrm{u}}=0.05$ corresponds to an equivalence ratio of 1.0 .

Figure 4 shows the isosurfaces for $f_{\mathrm{u}}=0.05$ and $\theta_{\text {post }}=11^{\circ}$ ATDC. ' $a$ ' shows the overhead views, 'b' shows views from the central axis of the cylinder, and 'c' shows side views perpendicular to the spray direction. The blue surfaces indicate the isosurfaces by main injection, and green surfaces indicate those by post injection. The red points indicate the fuel droplets. The mixture by main injection impinges around the squish lip. Part of the mixture enters the squish area,

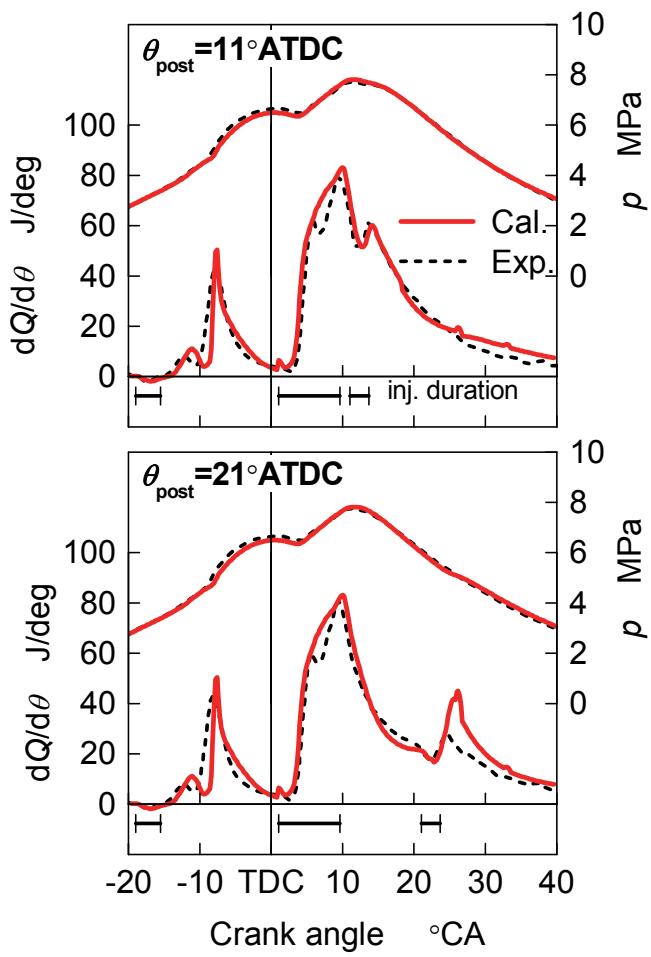

Figure 3 Comparison of the heat-release rate $\mathrm{d} Q / \mathrm{d} \theta$ and in-cylinder pressure $p$ between the experimental and computational results $\left(\theta_{\text {post }}=11^{\circ}\right.$ ATDC and $21^{\circ}$ ATDC).

and the rest spreads along the side wall of the piston bowl. Thus, the spreading mixture meets the mixture from the adjacent spray and creates a bulge ('A'). The bulge grows and reaches the bottom of the bowl, then begins to move along the bottom surface, and also begins to spread upward ('B'), which approaches the path of the post spray. The mixture by post injection impinges on the squish lip at $16^{\circ} \mathrm{ATDC}$, which is $5^{\circ} \mathrm{CA}$ after the start of post injection; then, a large part of the mixture enters the squish area. The impinging point deviates approximately $6^{\circ}$ from the injection direction owing to the effect of swirl flow.

In order to examine the overall distribution of the mixture fraction in the cylinder, histograms for the mixture fraction were calculated. Figure 5 shows the histogram for the case without post injection at each crank angle, where the total injection quantity is the same as the case with post injection. Here, the graph shows the mixture mass contained in each section of the mixture fraction (the step size is 0.005). At $10^{\circ}$ ATDC just after the end of main injection, the mixture-mass distribution is broad, and there is a considerable amount of rich mixture with $f_{u}>0.1$. As time elapses, the range of the mixture fraction becomes narrower, and the peak around $f_{\mathrm{u}}=0.05$ increases, which indicates the progress of fuel-air mixing. Figure 6 shows the histogram for post injection for $\theta_{\text {post }}=11^{\circ}$ ATDC. It should be noted that the main injection quantity is reduced to maintain the total injection quantity. At $10^{\circ}$ ATDC, a very rich mixture with $f_{\mathrm{u}}>0.15$ decreases compared with Fig. 5 because the main injection quantity is smaller. At $15^{\circ}$ ATDC just after the end of post injection, a rich mixture with $f_{u}>0.12$ is observed, which is not observed in Fig. 5. This is due to the addition of fuel by 

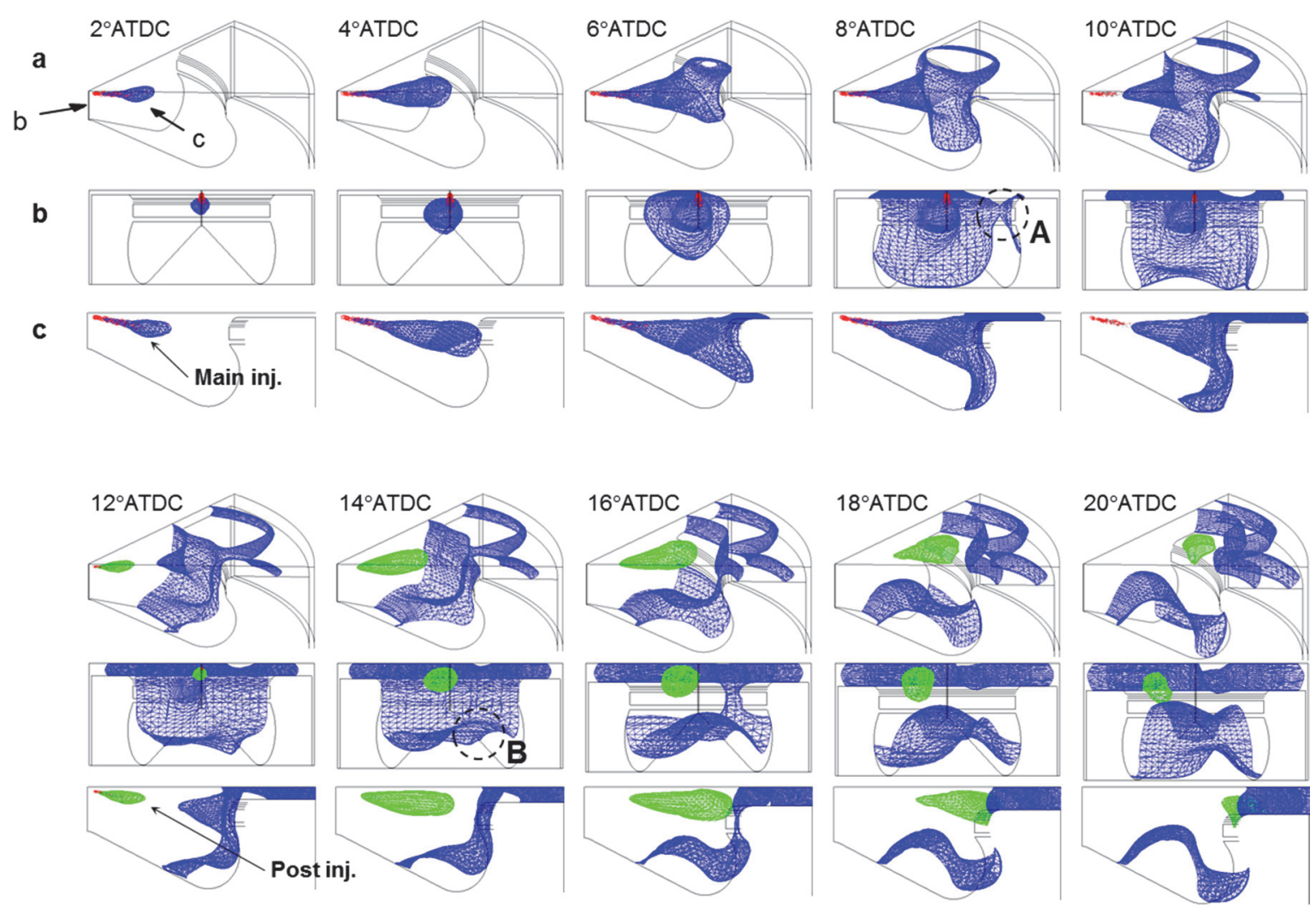

Figure 4 Isosurfaces for a mixture fraction $f_{u}=0.05$ (seven-hole nozzle, $\theta_{\text {post }}=11^{\circ} \mathrm{ATDC}$ ).

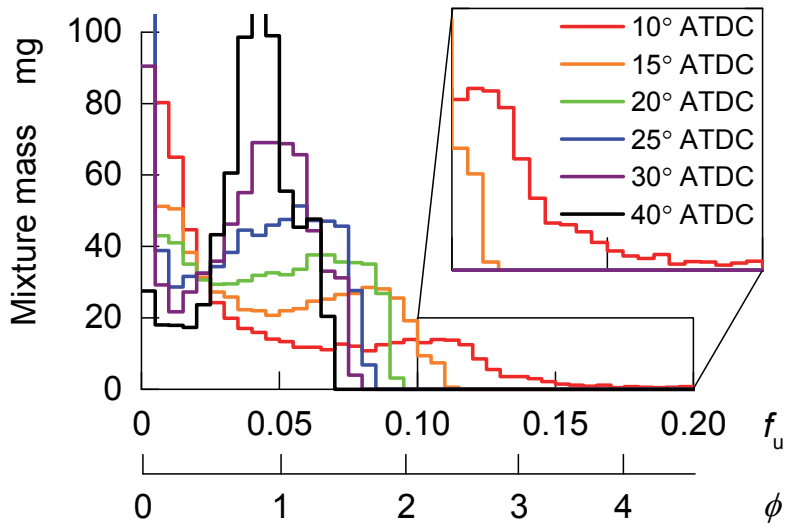

Figure 5 Histograms for the mixture fraction $f_{\mathrm{u}}$ (sevenhole nozzle, without post injection, main-injection quantity: $\left.27 \mathrm{~mm}^{3}\right)$.

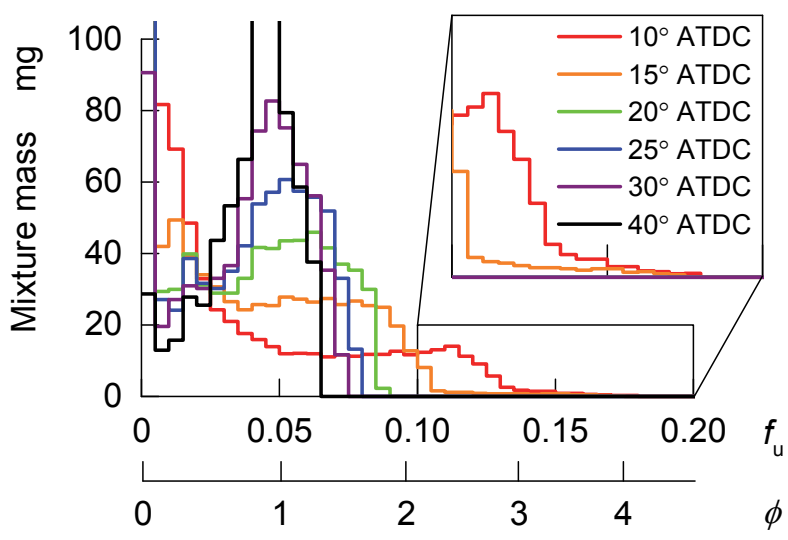

Figure 6 Histograms for the mixture fraction $f_{u}$ (sevenhole nozzle, $\theta_{\text {post }}=11^{\circ}$ ATDC). post injection. The trend in the distribution after $20^{\circ}$ ATDC obviously indicates the formation of a leaner mixture than that in Fig. 5.

To represent the effect of post injection on the overall fuel-air mixing more clearly, the differences in the mixture-mass distribution between the cases with and without post injection were calculated. Figure 7 shows the results (the distribution in Fig. 6 minus that in Fig. 5 for each crank angle) for $\theta_{\text {post }}=11^{\circ}$ ATDC. The positive mass difference means the increase in the mixture mass by post injection. The increases in the positive mass difference around $f_{u}=0.05$ and the negative mass difference at higher $f_{u}$ indicate the formation of leaner mixtures in the case with post injection.

Using the same method, the effect of the post-injection timing on the mixture-mass distribution was examined. The mixture-mass differences for the same crank angle after the start of post injection were compared at crank angles of $5^{\circ}$ and $9^{\circ} \mathrm{ASl}$ post (after the start of post injection), which correspond to the timings when the post spray is not yet lean, and the mixing progresses to some extent (see Fig. 6). Figure 8 and 9 show the results for $5^{\circ}$ and $9^{\circ} \mathrm{ASl}$ post.

At $5^{\circ} \mathrm{ASI}_{\text {post, }}$, rich mixtures with $f_{\mathrm{u}}>0.1$ increase for every post-injection timing owing to the addition of fuel by post injection (Fig. 8); however, this increase is not observed at $9^{\circ} \mathrm{ASl}_{\text {post }}$ (Fig. 9). In Fig. 9, the mass differences around $f_{u}=0.05$, except for $\theta_{\text {post }}=21^{\circ}$ ATDC, increase compared with those in Fig. 8. However, an obvious change in the mass difference is not observed for $\theta_{\text {post }}=21^{\circ}$ ATDC. This 


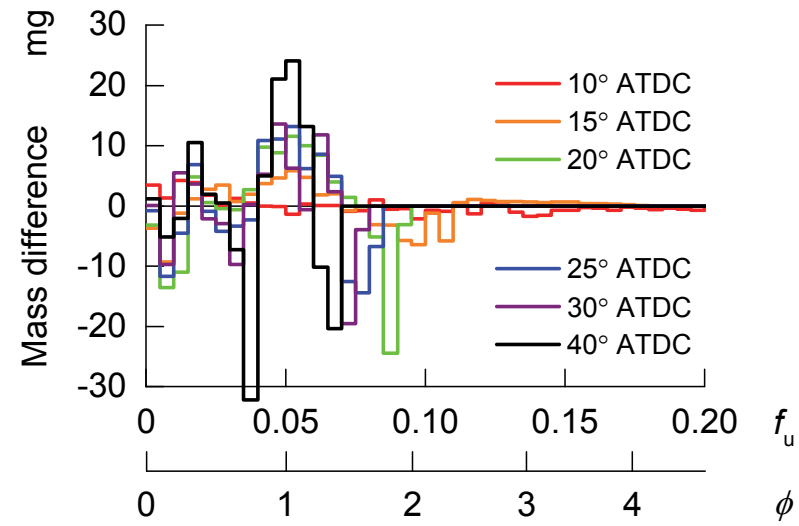

Figure 7 Mass-difference against the mixture fraction $f_{\mathrm{u}}$ for $\theta_{\text {post }}=11^{\circ}$ ATDC (seven-hole nozzle).

means that it is difficult to form lean mixtures in the case of late post injection.

To explain the reason for this phenomenon, the distributions of $f_{\mathrm{u}}$ and $T$ are compared for $\theta_{\text {post }}=11^{\circ}$ ATDC and $21^{\circ}$ ATDC in Fig. 10 and 11. The displayed surfaces are in a cross section at $6^{\circ}$ from the injection direction along the swirl flow because the post spray is shifted by the swirl flow, as already described. As shown in Fig. 10, the main spray is injected into the high-temperature area formed by the combustion of pilot injection at $2^{\circ}$ ATDC. At $6^{\circ}$ ATDC, the temperature exceeds $2,000 \mathrm{~K}$ near the squish lip, where the mixture fraction is in the range from 0.1 to 0.2 . The tail of the main spray immediately becomes lean after the end of injection (from $10^{\circ} \mathrm{ATDC}$ to $14^{\circ} \mathrm{ATDC}$ ). The post spray is injected into the lean area where the temperature is

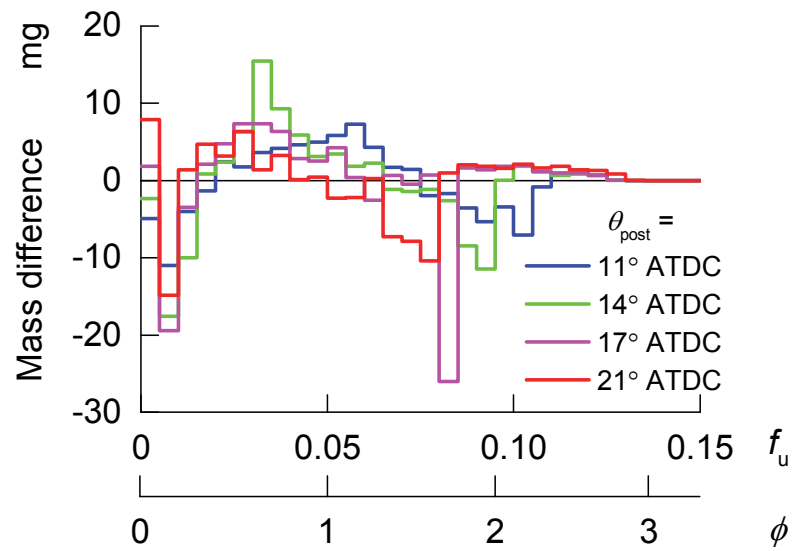

Figure 8 Mass-difference against the mixture fraction $f_{\mathrm{u}}$ at $5^{\circ} \mathrm{ASI}_{\text {post }}$ (seven-hole nozzle).

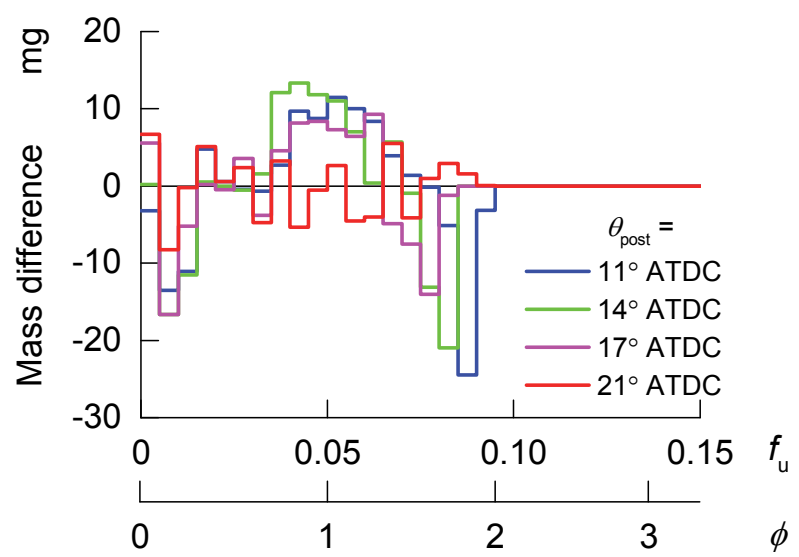

Figure 9 Mass-difference against the mixture fraction $f_{\mathrm{u}}$ at $9^{\circ}$ ASl post (seven-hole nozzle).

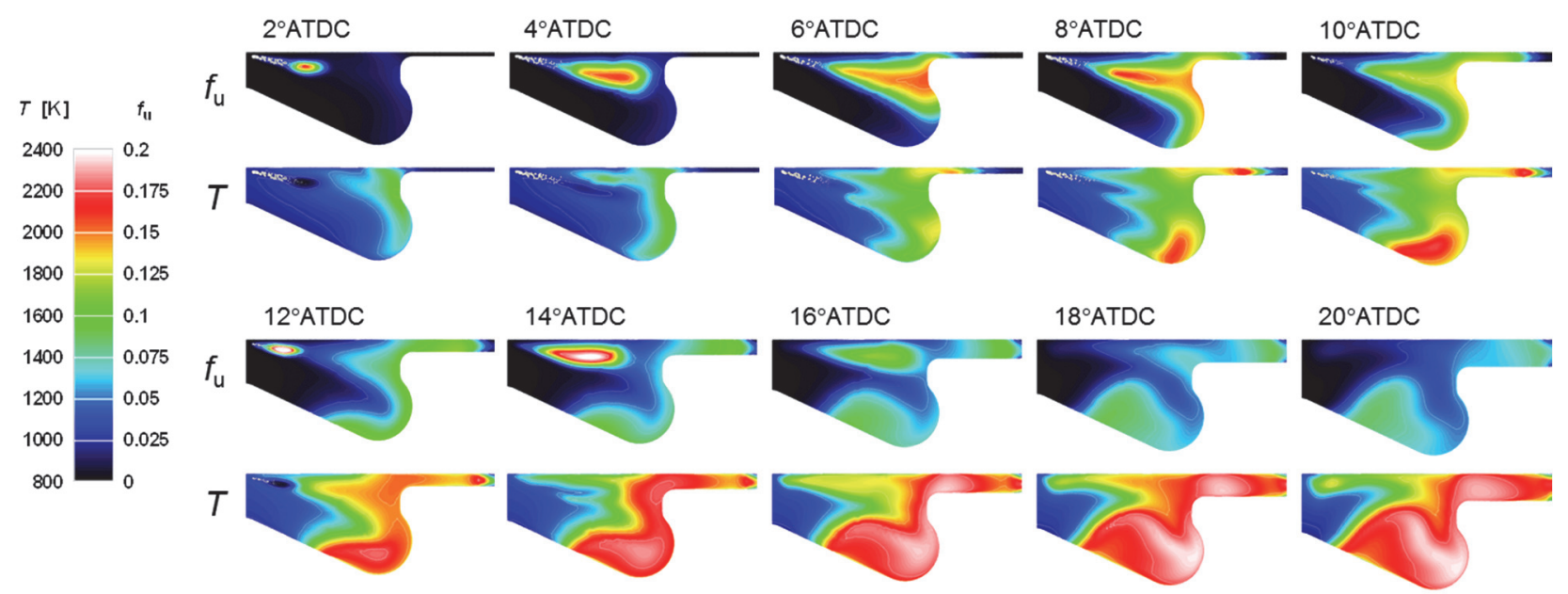

Figure 10 Distributions of the mixture fraction $f_{u}$ and temperature $T$ (seven-hole nozzle, $\theta_{\text {post }}=11^{\circ}$ ATDC).

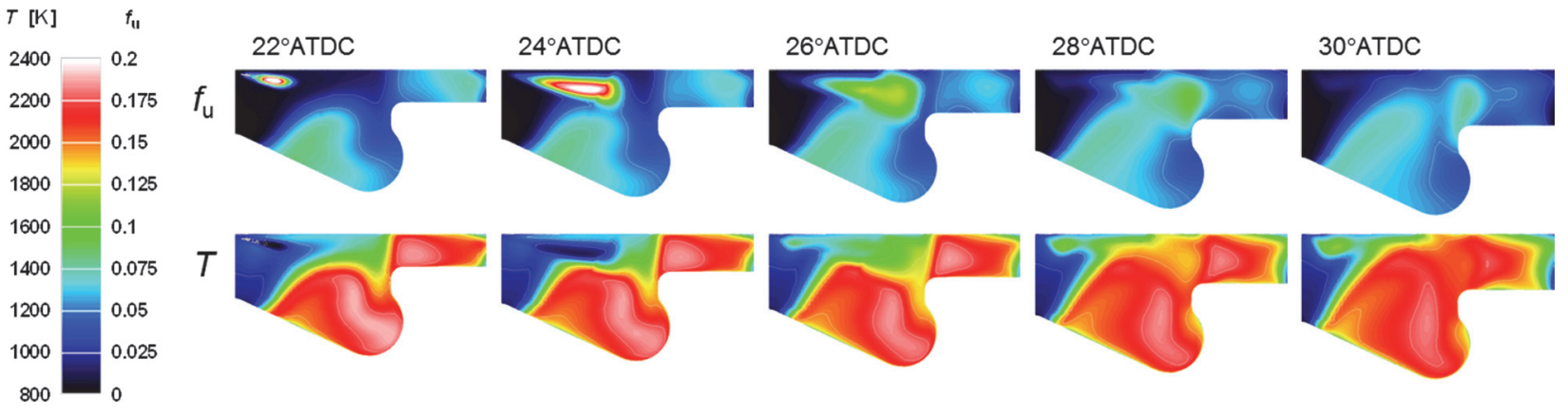

Figure 11 Distributions of the mixture fraction $f_{u}$ and temperature $T$ (seven-hole nozzle, $\theta_{\text {post }}=21^{\circ}$ ATDC). 
low. In Fig. 11, the high-mixture-fraction area formed by main-spray combustion spreads upward from the bottom of the piston bowl and reaches the path of the post spray at $22^{\circ} \mathrm{ATDC}$, where the temperature is very high. At $24^{\circ}$ ATDC, the post spray penetrates the high-mixture-fraction and high-temperature area. This leads to reduced utilization of oxygen by the post spray.

According to the above results, an explanation can be proposed for the difference in smoke emission between early and late post injection as follows. In the case of early post injection, the post sprays utilize oxygen without interference from the main-spray flames (Fig. 10). This suppresses soot emission from the post-spray combustion. In addition, a reduced quantity of main injection provides leaner mixtures in the main-spray flame (Fig. 9, $\theta_{\text {post }}=11^{\circ}$ ATDC), which reduces residual soot in the flame.

On the other hand, in the case of late post injection, oxygen utilization of the post spray is deteriorated owing to interference from the main-spray flame (Fig. 11). Thus, post-spray combustion is a source of soot emission. Furthermore, the oxygen utilization in the main-spray flame is obstructed, which delays the formation of leaner mixtures (Fig. 9, $\theta_{\text {post }}=21^{\circ}$ ATDC) and causes high soot emission.

\section{EFFECT OF NOZZLE SPECIFICATION}

The experiments were performed by varying the number of injection nozzle orifices with the same flow rate. Six-hole, eight-hole, and 10-hole nozzles were used in addition to the seven-hole nozzle. Only a slight difference was found in the injection-rate profiles of these nozzles.

Figure 12 shows the smoke emission, $\mathrm{O}_{2, \text { in }}$, and $\eta_{\mathrm{i}}$ versus $\theta_{\text {post. }}$ For the case without post injection, the smoke of the eight-hole nozzle is relatively low, and that of the 10-hole nozzle is relatively high. An increase in the number of nozzle orifices with a smaller orifice reduces the injection quantity from each orifice, which makes the mixture leaner and would reduce smoke emission. However, for a nozzle with a large number of orifices, the momentum of each spray is lower owing to the smaller orifice. After the impingement of the spray on the piston bowl, the spreading of the spray and the fuel-air mixing would be slower.

Smoke emission was reduced by advanced post injection for six-, seven- and eight-hole nozzles. The smoke-emission tendency for the six- and eight-hole nozzles can be explained in the same manner as the seven-hole nozzle. On the other hand, for the 10-hole nozzle, the use of more advanced post injection from $17^{\circ}$ ATDC to $11^{\circ}$ ATDC caused an increase in smoke emission. To explain the reason for this phenomenon, a CFD simulation for the 10-hole nozzle was conducted.

Figure 13 shows the experimental and computational heat-release rates for $\theta_{\text {post }}=11^{\circ}$ ATDC and $\theta_{\text {post }}=17^{\circ}$ ATDC. The results for the seven-hole nozzle are also displayed as a reference. In the experiment for the 10-hole nozzle, the heat-release rates by pilot

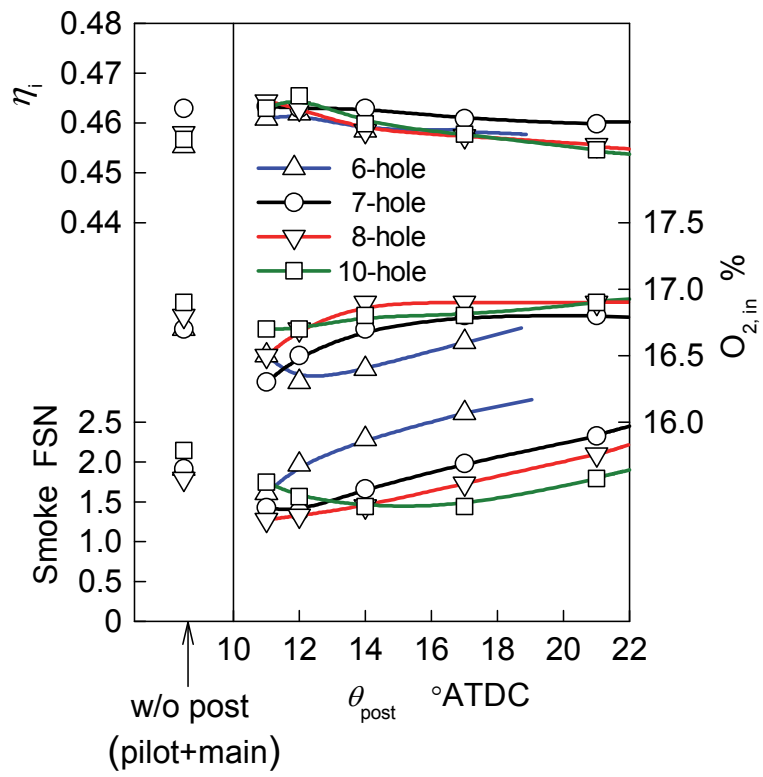

Figure 12 Effects of the nozzle specification on the indicated thermal efficiency $\eta_{\text {intake intaken }}$ concentration $\mathrm{O}_{2}$,in, and smoke emission (experimental results).

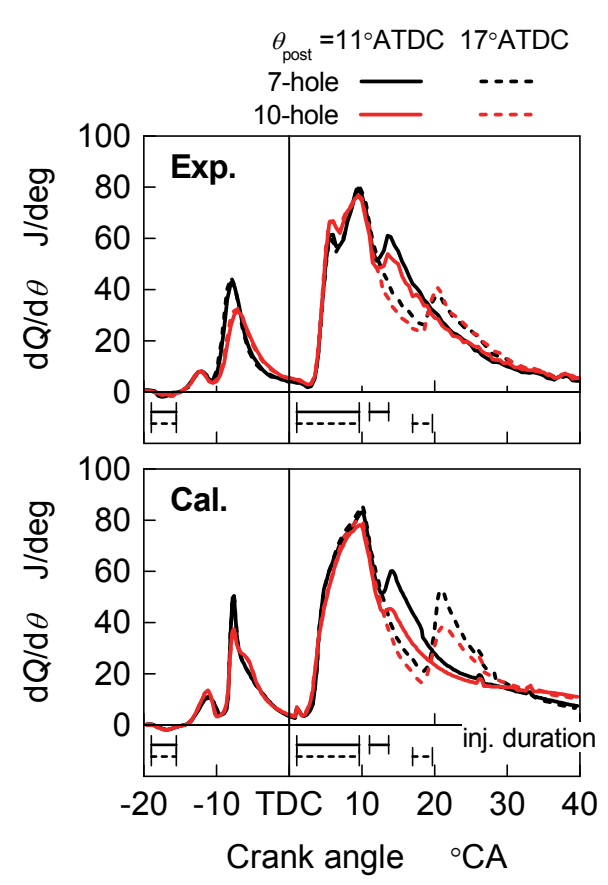

Figure 13 Comparison of the heat-release rate $\mathrm{d} Q / \mathrm{d} \theta$ between the experimental and computational results (10-hole and seven-hole nozzles, $\theta_{\text {post }}=11^{\circ}$ and $17^{\circ}$ ATDC).

injection are lower, and the initial heat-release rates by main injection are slightly higher compared with the seven-hole nozzle. The heat-release rate by post injection is lower than that of the seven-hole nozzle for $\theta_{\text {post }}=11^{\circ}$ ATDC, whereas it is not much different for $\theta_{\text {post }}=17^{\circ}$ ATDC. The calculated heat-release rates are in good agreement with the experimental data.

The isosurfaces for $f_{u}=0.05$ are shown in Fig. 14 for $\theta_{\text {post }}=11^{\circ}$ ATDC. Compared with the results in Fig. 4 for a seven-hole nozzle, the development of the main spray is slower, and the main-spray tail in the post- 


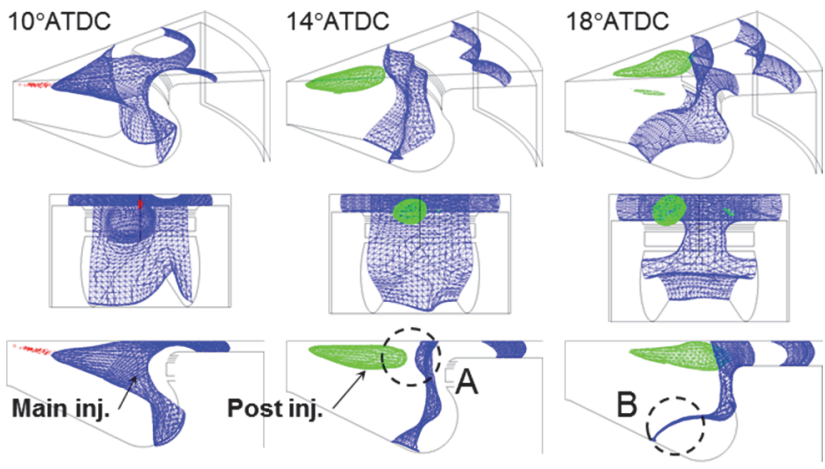

Figure 14 Isosurfaces for the mixture fraction $f_{\mathrm{u}}=0.05$ (10-hole nozzle, $\theta_{\text {post }}=11^{\circ}$ ATDC $)$.

spray path remains for a long time. As a result, the post spray enters the mixture remaining around the squish lip ('A'). In addition, the spread of the main-spray flame along the piston-bowl bottom ('B') is narrower compared with the seven-hole nozzle (Fig. 4).

Figure 15 and 16 show the histograms for the mixture fraction without and with post injection for $\theta_{\text {post }}=11^{\circ}$ ATDC. In both graphs, a delay in the formation of a leaner mixture is obviously observed compared with the seven-hole nozzle (Fig. 5 and 6). This is caused by the narrower mixture distribution, as described in Fig. 14.

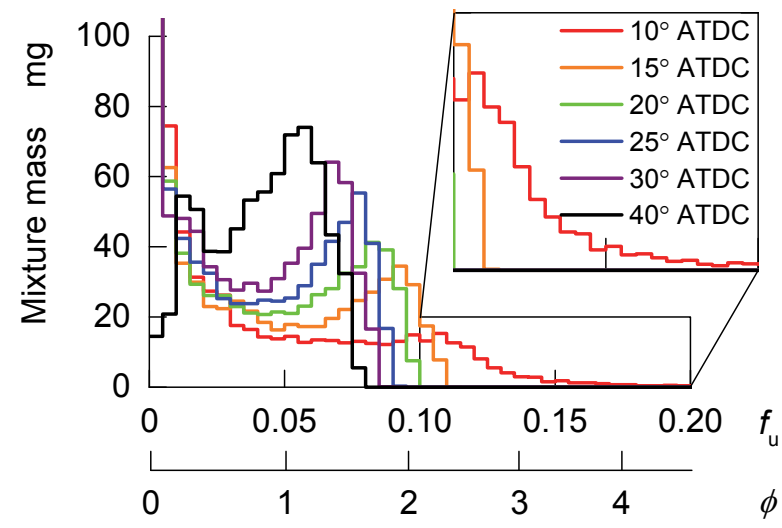

Figure 15 Histograms for the mixture fraction $f_{u}$ (10-hole nozzle, without post injection, main-injection quantity: $27 \mathrm{~mm}^{3}$ ).

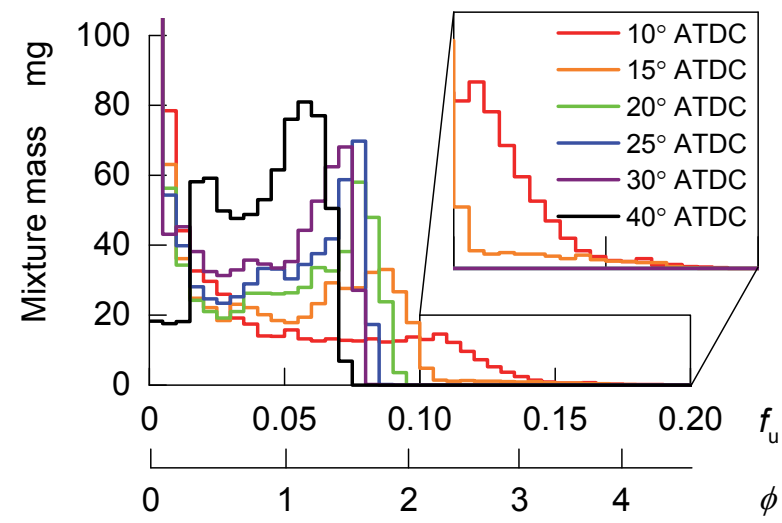

Figure 16 Histograms for the mixture fraction $f_{\mathrm{u}}$ (10-hole nozzle, $\theta_{\text {post }}=11^{\circ}$ ATDC).

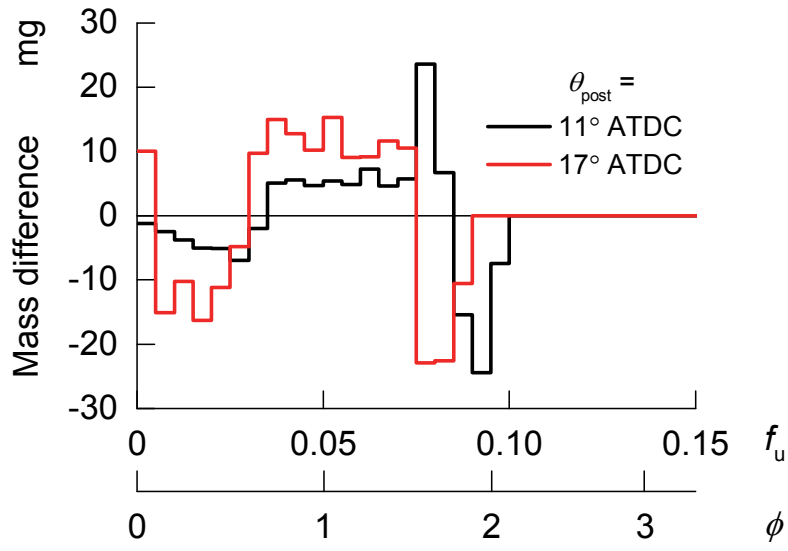

Figure 17 Mass-difference against the mixture fraction $f_{\mathrm{u}}$ at $9^{\circ} \mathrm{ASl}$ post (10-hole nozzle).

The mixture-mass difference at $9^{\circ}$ ASlpost was analyzed in the same manner as in Fig. 8. Figure 17 shows the results for $\theta_{\text {post }}=11^{\circ}$ ATDC and $17^{\circ}$ ATDC. The amount of mixture around $f_{u}=0.05$ is greater than the case without post injection for both post-injection timings. This tendency is more remarkable for later post injection ( $\theta_{\text {post }}=17^{\circ}$ ATDC), which is contrary to the case for the seven-hole nozzle (Fig. 9).

The distributions of $f_{\mathrm{u}}$ and $T$ are compared for $\theta_{\text {post }}=11^{\circ}$ ATDC and $17^{\circ}$ ATDC in Fig. 18 and 19. The rich tail of the main spray remains longer $\left(12^{\circ}\right.$ ATDC in Fig. 18) compared with the case of the seven-hole nozzle (Fig. 10). The post spray for $\theta_{\text {post }}=11^{\circ}$ ATDC penetrates the rich area. On the other hand, in the case of $\theta_{\text {post }}=17^{\circ}$ ATDC (Fig. 19), the post spray develops within the leaner and lower-temperature area because the tail of the main spray becomes leaner and the main-spray flame from the bowl bottom does not reach the path of post spray yet.

According to the above results, an explanation can be proposed for the smoke-emission trend of the 10-hole nozzle as follows. In the case of early post injection, the oxygen utilization of the post sprays is deteriorated owing to interference from the tail of the main spray (Fig. 18), which delays the formation of leaner mixtures (Fig. $17, \theta_{\text {post }}=11^{\circ}$ ATDC) and causes high soot emission, although the soot emission is lower than that of the case without post injection owing to the reduced quantity of main injection. In case of moderately late post injection, the post sprays utilize oxygen owing to less interference from the main-spray flames (Fig. 19). This suppresses soot emission from the post-spray combustion, which leads to a larger reduction in smoke emission than early post injection.

\section{EFFECT OF INJECTION PRESSURE}

As described above, the smoke tendency of the 10hole nozzle is caused by the slow development of main spray and flame. Higher injection pressure accelerates the development of spray and flame, and would shift the smoke tendency to that similar to the seven-hole nozzle. Therefore, experiments at an injection pressure of $130 \mathrm{MPa}$ with a 10-hole nozzle were conducted. The injection pressure was selected to 

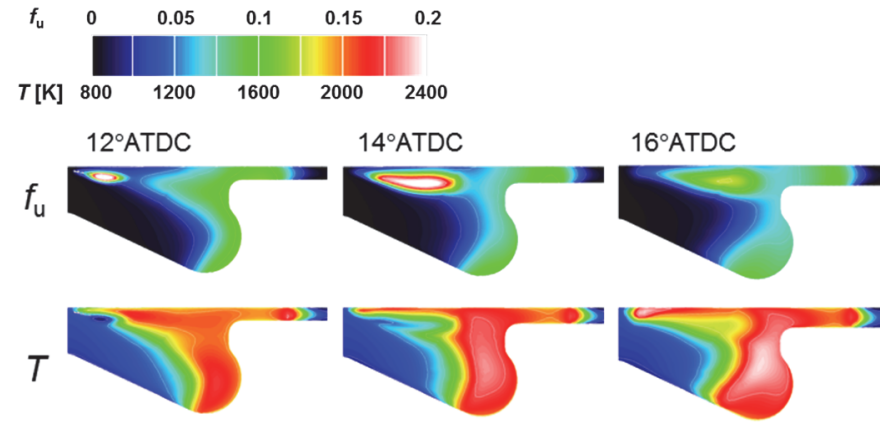

Figure 18 Distributions of the mixture fraction $f_{\mathrm{u}}$ and temperature $T\left(10\right.$-hole nozzle, $\theta_{\text {post }}=11^{\circ}$ ATDC $)$.
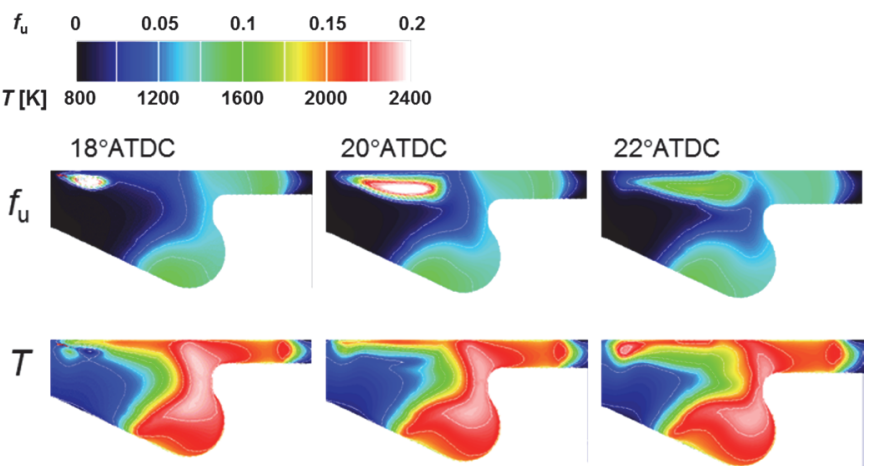

Figure 19 Distributions of the mixture fraction $f_{\mathrm{u}}$ and temperature $T$ (10-hole nozzle, $\theta_{\text {post }}=17^{\circ}$ ATDC).

make the spray tip penetration profile with a 10-hole nozzle comparable to that with a seven-hole nozzle and an injection pressure of $90 \mathrm{MPa}$ based on Wakuri's momentum theory [25].

Figure 20 shows the experimental results versus $\theta_{\text {post. }}$ Overall, a high injection pressure reduced smoke emission, and smoke emission was reduced for more advanced post injection. The smoke tendency was similar to the other injection nozzles with an injection pressure of $90 \mathrm{MPa}$.

Figure 21 shows the heat-release rates for $\theta_{\text {post }}=11^{\circ}$ and $17^{\circ}$ ATDC from the experiments and CFD calculations. In the experiments, the peak of the heat-release rate of pilot injection becomes lower, and that of main injection increases as the injection pressure increases. The heat-release rate for post injection seems to be barely affected by the injection pressure. The calculated heat-release rates are in good agreement with the experimental results, although the heat-release rates for post injection at $\theta_{\text {post }}=17^{\circ} \mathrm{ATDC}$ for $p_{\mathrm{j}}=130 \mathrm{MPa}$ are higher than those in the experiment.

Figure 22 shows the histograms for the mixture fraction without post injection. Compared with $p_{\mathrm{j}}=90 \mathrm{MPa}$ (Fig. $15)$, progress in the formation of a leaner mixture is obviously observed.

Figure 23 shows the mixture-mass difference at $5^{\circ}$ ASI post for $\theta_{\text {post }}=11^{\circ} \mathrm{ATDC}$ and $17^{\circ} \mathrm{ATDC}$. The post injection timing hardly affected the amount of mixture around $f_{\mathrm{u}}=0.05$.

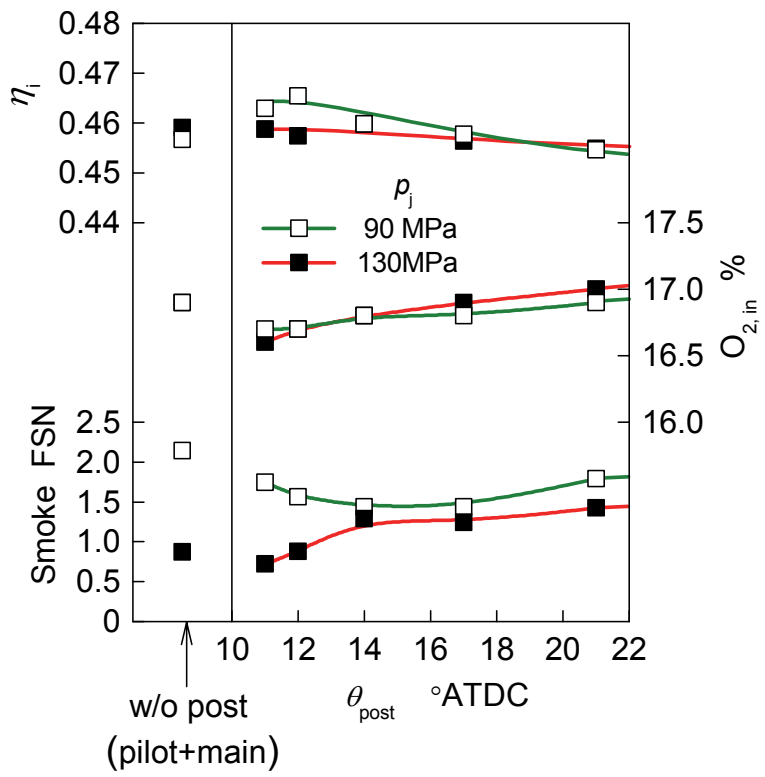

Figure 20 Effects of the injection pressure $p_{\mathrm{j}}$ on the indicated thermal efficiency $\eta_{\text {i }}$, intake oxygen concentration $\mathrm{O}_{2}$,in, and smoke emission (experimental results, 10-hole nozzle).

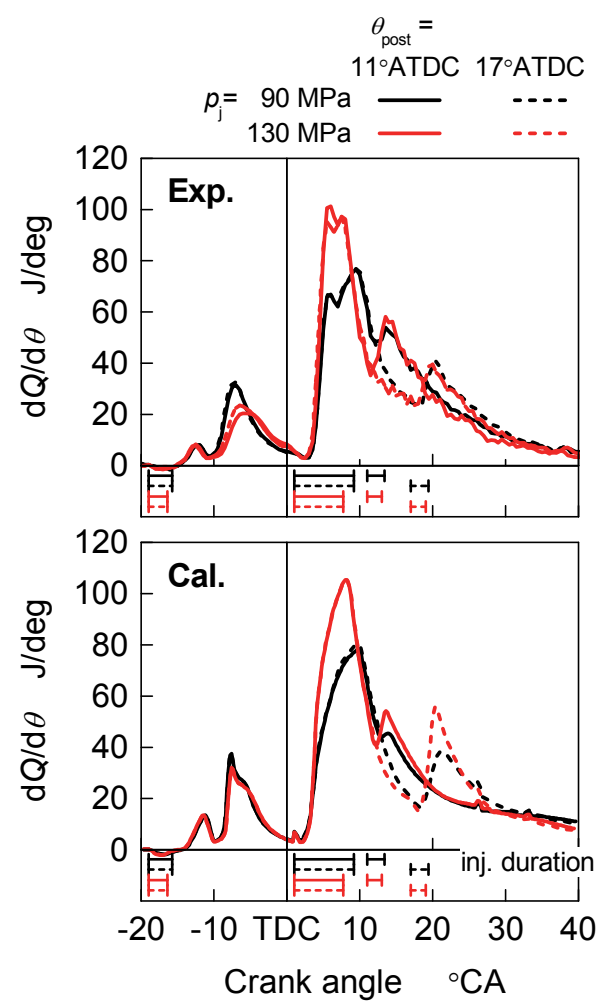

Figure 21 Comparison of the heat-release rate $\mathrm{d} Q / \mathrm{d} \theta$ between the experimental and computational results (10-hole nozzle, $p_{\mathrm{j}}=90 \mathrm{MPa}$ and $130 \mathrm{MPa}$,

$\theta_{\text {post }}=11^{\circ}$ ATDC and $17^{\circ}$ ATDC).

The distributions of $f_{\mathrm{u}}$ were compared between $\theta_{\text {post }}=11^{\circ}$ ATDC and $17^{\circ}$ ATDC at $p_{\mathrm{j}}=130 \mathrm{MPa}$. Figure 24 shows the distributions of $f_{u}$ at $3^{\circ}$ ASlpost $\left(14^{\circ}\right.$ ATDC for $\theta_{\text {post }}=11^{\circ}$ ATDC and $20^{\circ}$ ATDC for $\theta_{\text {post }}=17^{\circ}$ ATDC), where the difference between the injection pressures was comprehensible. The tail of the main spray for $p_{\mathrm{j}}=130 \mathrm{MPa}$ at $\theta_{\text {post }}=11^{\circ}$ ATDC is leaner than $p_{\mathrm{j}}=90 \mathrm{MPa}$. The main-spray bulge for $p_{\mathrm{j}}=130 \mathrm{MPa}$ at $\theta_{\text {post }}=17^{\circ}$ ATDC spreads upward and approaches the path of the post spray. However, the 


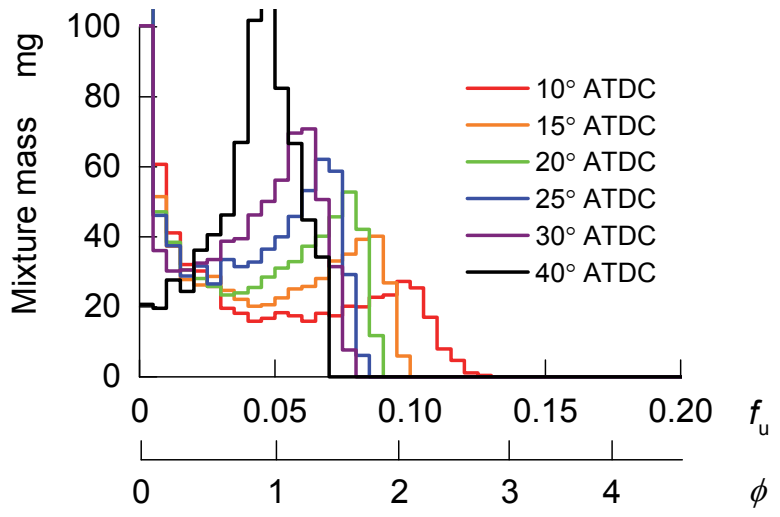

Figure 22 Histograms for the mixture fraction $f_{u}$ (10-hole nozzle, without post injection, main-injection quantity: $27 \mathrm{~mm}^{3}, \quad p_{\mathrm{j}}=130 \mathrm{MPa}$ ).

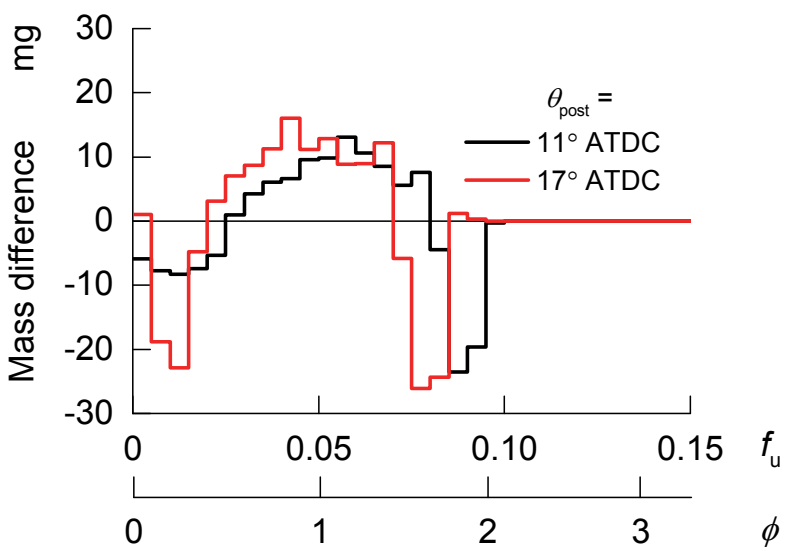

Figure 23 Mass-difference against the mixture fraction $f_{\mathrm{u}}$ at $5^{\circ}$ ASl post $\left(10\right.$-hole nozzle, $p_{\mathrm{j}}=130 \mathrm{MPa}$ ).
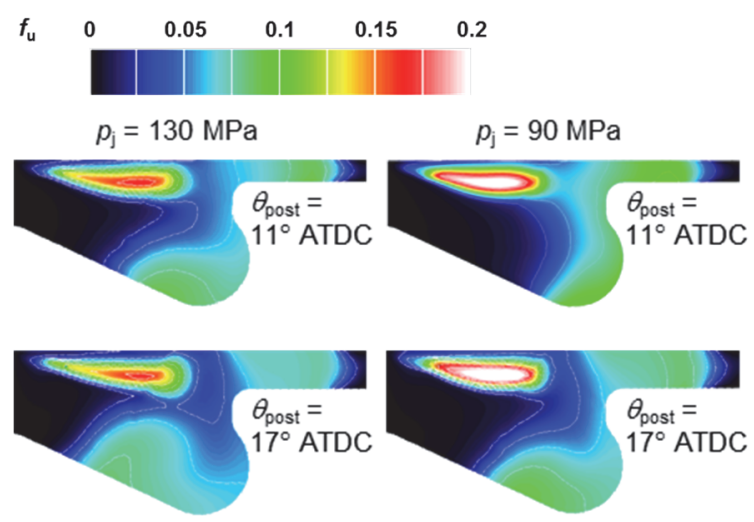

Figure 24 Distributions of the mixture fraction $f_{\mathrm{u}}$ at $3^{\circ}$ ASI $_{\text {post }}$ (10-hole nozzle, $p_{\mathrm{j}}=130 \mathrm{MPa}$ and $90 \mathrm{MPa}$, $\theta_{\text {post }}=11^{\circ}$ and $17^{\circ}$ ATDC $)$.

result in Fig. 23 indicates that the marked deterioration of oxygen utilization of post spray is not observed yet.

Thus the elevation of injection pressure makes the main-spray flame leaner, which weakens the interference between the tail of the main-spray flame and the post spray. This reduces the smoke emission for early post injection in the 10-hole nozzle.

\section{SUMMARY AND CONCLUSIONS}

An experimental study was carried out to investigate the effects of post injection on smoke emission using a small-bore single-cylinder diesel engine and changing the post-injection timing $\left(11-21^{\circ}\right.$ ATDC) using various numbers of nozzle orifices (6-10 orifices) with the same hydraulic flow rate and injection pressure for a 10-hole nozzle. To explain the smoke tendency against the above parameters, an analysis of the mixture formation process was performed using a CFD simulation. The following conclusions are derived:

- For the nozzles with six through eight orifices, smoke emission monotonously decreases as the post injection is advanced. On the other hand, in the case of the 10-hole nozzle, smoke emission increases when the post injection is advanced from the moderately late timing ( $17^{\circ}$ ATDC).

- CFD results indicate that the early post injection mitigates the interference of the main spray flame on the post spray for the seven-hole nozzle.

- In the case of early post injection for the ten-hole nozzle, the post spray entrains low-oxygen gas caused by the tail of main spray flame, which leads to high smoke emission.

- Even for the ten-hole nozzle, promoting spray development by elevated injection pressure provides the similar smoke trend to the sevenhole nozzle.

\section{REFERENCES}

1. Han, Z., Uludogan, A., Hampson, G., and Reitz, R., "Mechanism of Soot and NOx Emission Reduction Using Multiple-Injection in a Diesel Engine," SAE Technical Paper 960633, 1996, doi:10.4271/960633.

2. Chen, S., "Simultaneous Reduction of NOx and Particulate Emissions by Using Multiple Injections in a Small Diesel Engine," SAE Technical Paper 2000-01-3084, 2000, doi:10.4271/2000-01-3084

3. Badami, M., Mallamo, F., Millo, F., and Rossi, E., "Influence of Multiple Injection Strategies on Emissions, Combustion Noise and BSFC of a DI Common Rail Diesel Engine," SAE Technical Paper 2002-01-0503, 2002, doi:10.4271/2002-010503.

4. Beatrice, C., Belardini, P., Bertoli, C., Lisbona, M.G., and Rossi Sebastiano, G.M., "Diesel Combustion Control in Common Rail Engines by New Injection Strategies," Int. J. Eng. Research 3(1):23-36, 2002, doi: 10.1243/1468087021545513.

5. Park, C., Kook, S., and Bae, C., "Effects of Multiple Injections in a HSDI Diesel Engine Equipped with Common Rail Injection System," SAE Technical Paper 2004-01-0127, 2004, doi:10.4271/2004-01-0127.

6. Hotta, Y., Inayoshi, M., Nakakita, K., Fujiwara, K. and Sakata, I., "Achieving Lower Exhaust Emissions and Better Performance in an HSDI 
Diesel Engine with Multiple Injection," SAE Technical Paper 2005-01-0928, 2005, doi:10.4271/2005-01-0928.

7. Dronniou, N., Lejeune, M., Balloul, I., and Higelin, P., "Combination of High EGR Rates and Multiple Injection Strategies to Reduce Pollutant Emissions," SAE Technical Paper 2005-01-3726, 2005, doi:10.4271/2005-01-3726.

8. Desantes, J., Arrègle, J., López, J.J., and García, A., "A Comprehensive Study of Diesel Combustion and Emissions with Post-Injection," SAE Technical Paper 2007-01-0915, 2007, doi:10.4271/2007-01-0915.

9. Arrègle, J., Pastor, J.V., López, J.J., and García, A., "Insights on Post Injection-Associated Soot Emissions in Direct Injection Diesel Engines," Combustion and Flame 154(3):448-461, 2008, doi:10.1016/j.combustflame.2008.04.021.

10. Ogawa, H., Yoshida, T., Takahashi, K., and Numata, A., "Improvements in Diesel Combustion with After-Injection," SAE Technical Paper 200801-2476, 2008, doi:10.4271/2008-01-2476.

11. Ikemoto, M., Omae, K., and Nishida, K., "InCylinder Experimental Analysis Using PiezoDriven Diesel Injector Equipped With Needle-Lift Sensor," JSAE Trans., 41(6):1347-1352, 2010. (in Japanese)

12. Bobba, M., Musculus, M., and Neel, W., "Effect of Post Injections on In-Cylinder and Exhaust Soot for Low-Temperature Combustion in a HeavyDuty Diesel Engine," SAE Int. J. Engines 3(1):496-516, 2010, doi:10.4271/2010-01-0612.

13. Barro, C., Tschanz, F., Obrecht, P., and Boulouchos, K., "Influence of Post-Injection Parameters on Soot Formation and Oxidation in a Common-Rail Diesel Engine using Multi-ColorPyrometry," Proc. of ASME 2012 Internal Combustion Engine Division Fall Technical Conference, ICEF2012-92075:1-10, 2012.

14. Liu, L., Horibe, N., Komizo, T., Tamura, I., and Ishiyama, T., "An Experimental Study on Smoke Reduction Effect of Post Injection Combination With Pilot Injection for a Diesel Engine," J. Eng. Gas Turbines Power 136(4):041502, 2014, doi:10.1115/1.4025929.

15. O'Connor, J. and Musculus, M., "Post Injections for Soot Reduction in Diesel Engines: A Review of Current Understanding," SAE Int. J. Engines 6(1):400-421, 2013, doi:10.4271/2013-01-0917.

16. O'Connor, J. and Musculus, M., "In-Cylinder Mechanisms of Soot Reduction by Close-Coupled Post-Injections as Revealed by Imaging of Soot Luminosity and Planar Laser-Induced Soot Incandescence in a Heavy-Duty Diesel Engine," SAE Int. J. Engines 7(2):673-693, 2014, doi:10.4271/2014-01-1255.

17. Hessel, R., Reitz, R., Musculus, M., O'Connor, J., and Flowers, D., "A CFD Study of Post Injection Influences on Soot Formation and Oxidation under Diesel-Like Operating Conditions," SAE Int. J. Engines 7(2):694-713, 2014, doi:10.4271/201401-1256.

18. O'Connor, J. and Musculus, M., "Effects of Exhaust Gas Recirculation and Load on Soot in a
Heavy-Duty Optical Diesel Engine with CloseCoupled Post Injections for High-Efficiency Combustion Phasing," Int. J. Eng. Research 15(4):421-443, 2014, doi: 10.1177/1468087413488767.

19. O'Connor, J. and Musculus, M., "Effect of Load on Close-Coupled Post-Injection Efficacy for Soot Reduction in an Optical Heavy-Duty Diesel Research Engine," J. Eng. Gas Turbines Power 136(10):101509, 2014, doi: 10.1115/1.4027276.

20. Frapolli, N., Bolla, M., Boulouchos, K., and Wright, Y., "Simulations of In-Cylinder Processes in a Diesel Engine Operated with Post-Injections Using an Extended CMC Model," SAE Technical Paper 2014-01-2571, 2014, doi:10.4271/2014-012571.

21. Pandurangi, S.S., Frapolli, N., Bolla, M., Boulouchos, K., and Wright, Y.M., "Influence of EGR on Post-Injection Effectiveness in a HeavyDuty Diesel Engine Fuelled with n-Heptane," SAE Int. J. Engines 7(4):1851-1862, 2014, doi:10.4271/2014-01-2633.

22. Horibe, N., Komizo, T., Sumimoto, T., Wang, H. and Ishiyama, T., "Smoke Reduction Effects by Post Injection for Various Injection Parameters and Combustion Chamber Shapes in a Diesel Engine," SAE Technical Paper 2014-01-2634, 2014, doi:10.4271/2014-01-2634.

23. AVL FIRE Manual, v2010 ICE Physics \& Chemistry, 2010.

24. Kawanabe, H., Kojima, H., and Ishiyama, T., "Modeling of the Auto-ignition Process of a Nonhomogeneous Mixture in a Diesel Spray for CFD," SAE Technical Paper 2010-01-0357, 2010, doi:10.4271/2010-01-0357.

25. Wakuri, Y., Fujii, M., Amitani, T., and Tsuneya, R., "Studies of the Penetration of Fuel Spray in a Diesel Engine," Bulletin JSME 3(9):123-130, 1960.

\section{CONTACT}

Naoto HORIBE

Email: horibe@energy.kyoto-u.ac.jp

Website of lab.: http://cpel.energy.kyoto-u.ac.jp/

\section{ACKNOWLEDGMENTS}

Honda Motor Co., Ltd is acknowledged for providing the engine system. The authors would like to thank Mr. Masato YAGI for his valuable assistance with the experiments. 